\title{
Performance of Legumes-Turnip Mixtures with Different Seed Rates
}

\author{
Medine Çopur Doğrusöz ${ }^{*}$, Hanife Mut², Uğur Başaran³ ${ }^{3}$ Erdem Gülümser ${ }^{4}$ \\ ${ }^{1 *}$ Departmen of Field Crops, Faculty of Agriculture, Yozgat Bozok University, 66900 Yozgat, Turkey \\ Corresponding author, E-mail: medine.copur@bozok.edu.tr, ORCID: https://orcid.org/0000-0002-9159-1699 \\ ${ }^{2}$ Departmen of Field Crops, Faculty of Agriculture and Natural Science, Bilecik Seyh Edebali University, 11230 Bilecik, Turkey \\ E-mail: hanife.mut@bilecik.edu.tr, ORCID: https://orcid.org/0000-0002-5814-5275 \\ ${ }^{3}$ Departmen of Field Crops, Faculty of Agriculture, Yozgat Bozok University, 66900 Yozgat, Turkey \\ E-mail: ugur.basaran@bozok.edu.tr,ORCID: https://orcid.org/0000-0002-6644-5892 \\ ${ }^{4}$ Departmen of Field Crops, Faculty of Agriculture and Natural Science, Bilecik Seyh Edebali University, 11230 Bilecik, Turkey \\ E-mail: erdem.gulumser@bilecik.edu.tr, ORCID: https://orcid.org/0000-0001-6291-3831
}

\begin{tabular}{|c|c|}
\hline A R T I C LE IN F O & A B S T R A C T \\
\hline Research Article & $\begin{array}{l}\text { This study aimed to investigate appropriate seed rates for legume-turnip intercrops under different } \\
\text { harvest stages. Turnip (Brassica rapa } \text { L. var. rapa) was sown with common vetch (Vicia sativa }\end{array}$ \\
\hline Received : 17/07/2018 & L.), Hungarian vetch (Vicia pannonica Crantz) and pea (Pisum sativum ssp. arvense L. Poir) in \\
\hline Accepted : 25/12/2018 & 2014 with four different combinations (100\% legume, $75 \%$ legume $+25 \%$ turnip, $50 \%$ legume + \\
\hline Keywords: & $\begin{array}{l}50 \% \text { turnip, } 100 \% \text { turnip) and catted in two different times when the beginning and end of the } \\
\text { flowering of turnin. The study was conducted in Yozgat-Turkey with three replicates. Hav vield }\end{array}$ \\
\hline ADF & protein yield, ADF, NDF, Ca, Mg, P, K, Land Equivalent Ratio, Competitive Ratio and \\
\hline $\begin{array}{l}\text { Brassica } \\
\text { Intercropping }\end{array}$ & Aggressivity characteristics were determined in view of the combinations. The results of this \\
\hline LER & $0 \% \mathrm{HV}+50 \% \mathrm{~T}$ and sole pea harvested turnip was at the beginning of flowering stage were \\
\hline $\mathrm{NDF}$ & $\begin{array}{l}\text { the best treatments. On the other hand, when harvest was done at end of the flowering of turnip } \\
50 \% \mathrm{P}+50 \% \mathrm{~T}, 75 \% \mathrm{P}+25 \% \mathrm{~T} \text { and } 50 \% \mathrm{HV}+50 \% \mathrm{~T} \text { intercropping were the high yielding } \\
\text { treatment. }\end{array}$ \\
\hline
\end{tabular}

\section{Introduction}

One of the most important problems in the improvement of livestock is that high quality and cheap feed or forage cannot be meeting in sufficient quantity in Turkey. This is also the reason of high animal product prices, especially of meat prices. Forage crops are the most important resources of forage production. One of the effective methods to increase the yield and quality in forage culture is intercropping. In intercropping systems, mixtures of Leguminaceae and Graminaceae species are common phenomenon. In recent years, the combinations of the different plants in this field have been used. Use of combination of turnip and legumes possess high protein is an example for this concept (Ross et al., 2004).

Intercropping annual legumes with turnip is useful for weed competition and produces high quality forage (Tan and Serin, 1996; Anlarsal et al., 1996). Intercropping is potentially beneficial system of crop production and provides greater stability of yield compared to sole cropping under particular planting pattern owing to varying competitive behaviour of two crops (Bora, 1999). Rankin (1989) reported that intercropping of pea, vetch and small sized crops increases forage yield and quality. Intercropping of legumes with turnip was more beneficial than wheat and turnip intercropping (Prakash, 1992).

Turnip is a perennial and nutritious plant can be easily sown in both spring and autumn. It has many advantages for forage production due to being fast growing, having large amount of biomass and easily digestible. Turnip is a popular plant worldwide because of being used of nearly all parts (the roots, leaves and seedling) in animal feeding. Furthermore, it is considered that when turnip intercropped with legumes, higher forages yield and quality is maintained (Kumar et al., 2008). Turnip has some inhibitors (erucic acid, glycosides, sinapine, nitrate). For this reason, intercropping turnip with other plants is more advantageous than sole turnip (Hertrampf and Pascual 2000).

Appropriate sown rate and harvest time are very important for intercropping. In our study, the effect of seed ratio and growing stage on forage yield, quality and plant competition in turnip-legume intercropping were investigated. 


\section{Materials and Methods}

The study was carried out as two different experiments in Yerköy Experimental Field of Agriculture Faculty, Yozgat Bozok University in 2014-2015 growing season. Soil analysis and climatic conditions of experiment field during the growing season are shown in Table 1 and 2 respectively.

"Lenox" variety of turnip (Brassica rapa L. var. rapa), "Tamkoç 2000" variety of common vetch (Vicia sativa L.), "Altınova 2002" variety of Hungarian vetch (Vicia pannonica Crantz) and "Özkaynak" variety of pea (Pisum sativum ssp. arvense L. Poir) were used as plant material in the current study. The study was conducted randomized complete block design with three replicates. Turnip and legumes was manually sown as binary mixtures as six line with $20 \mathrm{~cm}$ distance and $5 \mathrm{~m}$ length. For sole cropping, seed rate was $1 \mathrm{~kg} / \mathrm{da}$ for turnip and $12 \mathrm{~kg} / \mathrm{da}$ for legumes (Avcioglu et al., 2009). Four seed combinations (100\% legume, $75 \%$ legume $+25 \%$ turnip, $50 \%$ legume $+50 \%$ turnip, $100 \%$ turnip) were used and, experiments were established in October $10^{\text {th }}, 2014$.

As fertilizer, DAP $\left(48 \% \mathrm{P}_{2} \mathrm{O}_{5}\right.$ and $\left.18 \% \mathrm{~N}\right)$ was applied to maintain $80 \mathrm{~kg} \mathrm{ha}^{-1}$ with sowing and plots were irrigated once after the sowing for germination. Both experiments were harvested based on the turnip stage. The first, it was at the beginning of flowering while the second was at the end of the turnip flowering. Forage samples were dried in $60^{\circ} \mathrm{C}$ and hay rates were determined with measuring dried samples. After grinding of dried samples by grass mill, crude protein, ADF (Acid Detergent Fiber), NDF (Neutral Detergent Fiber), $\mathrm{Ca}, \mathrm{Mg}, \mathrm{P}$ and $\mathrm{K}$ were determined in Near Infrared Reflectance Spectroscopy (NIR) (Foss 6500) with IC-0904FE program. Protein yield was determined with multiplying of crude protein rates and hay yield.

Land Equivalent Ratio (LER) was used in order to determine if intercropping has advantages compared with sole cropping in the environmental conditions. The comparisons are done with regard to 1 value, because sole cropping value is 1 in Land Equivalent Ratio (Smith et al., 2014).

Land Equivalent Ratio $(\mathrm{LER})=\mathrm{LER}_{\text {Turnip }}+\mathrm{LER}_{\text {Legume }}$

$\mathrm{LER}_{\mathrm{T}}=\mathrm{Y}_{\mathrm{TL}} / \mathrm{Y}_{\mathrm{TT}}, \mathrm{LER}_{\mathrm{L}}=\mathrm{Y}_{\mathrm{LT}} / \mathrm{Y}_{\mathrm{LL}}$.

$\mathrm{Y}_{\mathrm{TL}}$ : Turnip yield in intercropping,

$\mathrm{Y}_{\mathrm{LT}}$ : Legume yield intercropping,

$\mathrm{Y}_{\mathrm{TT}}$ : Turnip yield in sole cropping,

$Y_{L L}$ : Legume yield in sole cropping) (Willey, 1979).

Competitive ratio in mixtures (CR) was determined base on the method (Bantie et al., 2014) by using a formula reported by Willey and Rao, (1980).

Competitive Ratio Turnip $\left(\mathrm{CR}_{\mathrm{T}}\right)=\left(\mathrm{LER}_{\mathrm{T}} / \mathrm{LER}_{\mathrm{L}}\right)\left(\mathrm{X}_{\mathrm{LT}} / \mathrm{X}_{\mathrm{TL}}\right)$

Competitive ratiolegume $\left(\mathrm{CR}_{\mathrm{L}}\right)=\left(\mathrm{LER}_{\mathrm{L}} / \mathrm{LER}_{\mathrm{T}}\right)\left(\mathrm{X}_{\mathrm{TL}} / \mathrm{X}_{\mathrm{LT}}\right)$

$\mathrm{X}_{\mathrm{TL}}$ : Turnip sown ratio in intercropping

$\mathrm{X}_{\mathrm{LT}}$ : Tegume sown ratio in intercropping) (Willey and Rao, 1980).

Aggressivity of turnip $\left(\mathrm{A}_{\mathrm{T}}\right)=\left(\mathrm{Y}_{\mathrm{TL}} / \mathrm{Y}_{\mathrm{TT}} \times \mathrm{X}_{\mathrm{TL}}\right)-\left(\mathrm{Y}_{\mathrm{LT}} / \mathrm{Y}_{\mathrm{LL}} \mathrm{X}_{\mathrm{LT}}\right)$

Aggressivity of legume $\left(\mathrm{A}_{\mathrm{L}}\right)=\left(\mathrm{Y}_{\mathrm{LT}} / \mathrm{Y}_{\mathrm{LL}} \times \mathrm{X}_{\mathrm{LT}}\right)-\left(\mathrm{Y}_{\mathrm{TL}} / \mathrm{Y}_{\mathrm{TT}} \mathrm{X}_{\mathrm{TL}}\right)$

Aggressivity value can be positive or negative and refers dominancy the species in intercropping, also demonstrates which species is highly effective on yield. If aggressivity is zero, the effect of both crops on yield is equal. If aggressivity value of any species is positive, it is meaning that this species is dominant in the mixture and more effective on the yield (McGilchrist, 1965; Esmaeili et al. 2011).

The results were analyzed in MSTAT-C statistical program with randomized complete block design. The means were compared by the Duncan's test.

Table 1 Physical and Chemical Chacteristics of Soil in Research Area*

\begin{tabular}{c|cccccc}
\hline Structure & $\begin{array}{c}\text { Lime } \\
(\%)\end{array}$ & $\begin{array}{c}\text { Total Salt } \\
(\%)\end{array}$ & $\begin{array}{c}\text { Phosphours } \\
\left(\mathrm{kg} \mathrm{ha}^{-1}\right)\end{array}$ & $\begin{array}{c}\text { Potassium } \\
\left(\mathrm{kg} \mathrm{ha}^{-1}\right)\end{array}$ & $\mathrm{pH}$ & $\begin{array}{c}\text { Organic Matter } \\
(\%)\end{array}$ \\
\hline Clay-loam & 7.99 & 0.020 & 84.0 & 484.7 & 8.20 & 1.88 \\
\hline
\end{tabular}

*Turkish chamber of agriculture cooperation.

Table 2 Climatic conditions of during longterm and experimental years*

\begin{tabular}{l|rcrrrr}
\hline \multirow{2}{*}{ Months } & \multicolumn{3}{c}{ Long-term } & \multicolumn{2}{c}{$2014-2015$} \\
\cline { 2 - 7 } & $\begin{array}{c}\text { Temp. } \\
\left({ }^{\circ} \mathrm{C}\right)\end{array}$ & $\begin{array}{c}\text { Moist. } \\
(\%)\end{array}$ & $\begin{array}{c}\text { Precipt. } \\
(\mathrm{mm})\end{array}$ & $\begin{array}{c}\text { Temp. } \\
\left({ }^{\circ} \mathrm{C}\right)\end{array}$ & $\begin{array}{c}\text { Moist. } \\
(\%)\end{array}$ & $\begin{array}{c}\text { Precipt. } \\
(\mathrm{mm})\end{array}$ \\
\hline September & 15.5 & 58.1 & 18.0 & 20.1 & 49.4 & 24.7 \\
October & 10.3 & 65.9 & 36.5 & 10.8 & 69.3 & 72.6 \\
November & 4.6 & 72.5 & 56.2 & 4.2 & 70.2 & 61.3 \\
December & 0.5 & 77.3 & 76.3 & 4.1 & 77.9 & 53.3 \\
January & -1.9 & 77.5 & 67.9 & -1.0 & 76.7 & 54.5 \\
February & -1.0 & 75.8 & 62.3 & 0.8 & 73.3 & 68.0 \\
March & 2.9 & 71.0 & 65.2 & 4.4 & 69.5 & 115.3 \\
April & 8.3 & 66.6 & 62.3 & 6.1 & 61.9 & 28.0 \\
May & 13.0 & 64.2 & 65.0 & 14.1 & 59.9 & 131.6 \\
June & 16.8 & 60.5 & 43.5 & 16.0 & 71.5 & 95.3 \\
Average & 6.90 & 68.94 & & 7.96 & 67.96 & 704.6 \\
Total & & & 553.2 & & & \\
\hline
\end{tabular}

*Turkish State Meteorically Service 


\section{Results and Discussions}

\section{Experiment I}

All the investigated traits were significantly $(\mathrm{P}<0.01)$ affected by seed rates but NDF was affected at the level of $\mathrm{P}<0.05$.

In Exp I, the highest hay yield $(\mathrm{p}<0.01)$ was determined in sole turnip $\left(4.54 \mathrm{t} \mathrm{ha}^{-1}\right), 50 \% \mathrm{HV}+50 \% \mathrm{~T}\left(4.21 \mathrm{t} \mathrm{ha}^{-1}\right)$ and sole pea $\left(4.25 \mathrm{t} \mathrm{ha}^{-1}\right)$. The lowest hay yield was in common vetch $\left(1.59 \mathrm{t} \mathrm{ha}^{-1}\right)$.

Sole pea had the highest protein yield $\left(1.09 \mathrm{t} \mathrm{ha}^{-1}\right)$ at the the beginning of the flowering of turnip (Table 3 ). Common vetch had the lowest protein yield $\left(0.41 \mathrm{t} \mathrm{ha}^{-1}\right)$ as in the hay yield. Also protein yield was increased with rising turnip ratio in intercropping except common vetch + turnip mixtures. This result was similar with Lithourgidis, et al. (2006).

The highest ADF content was obtained in $75 \% \mathrm{HV}+$ $25 \% \mathrm{~T}$ combination $\left(402.50 \mathrm{~g} \mathrm{~kg}^{-1}\right)$ and $50 \% \mathrm{HV}+50 \% \mathrm{~T}$, $\left(400.90 \mathrm{~g} \mathrm{~kg}^{-1}\right), \quad 50 \% \mathrm{CV}+50 \% \mathrm{~T}\left(363.90 \mathrm{~g} \mathrm{~kg}^{-1}\right), 75 \% \mathrm{CV}$ $+25 \% \mathrm{~T}\left(369.50 \mathrm{~g} \mathrm{~kg}^{-1}\right), 50 \% \mathrm{P}+50 \% \mathrm{~T}\left(369.90 \mathrm{~g} \mathrm{~kg}^{-1}\right)$ and Sole Turnip (383.00 $\mathrm{g} \mathrm{kg}^{-1}$ ) were in the same statistical group. The lowest ADF content was in the common vetch $\left(303.00 \mathrm{~g} \mathrm{~kg}^{-1}\right)$. NDF content was statistically significant $(\mathrm{P}<0.05)$. Sole pea had the highest NDF value $\left(578.1 \mathrm{~g} \mathrm{~kg}^{-1}\right)$, while sole common vetch had the lowest value $\left(450.2 \mathrm{~g} \mathrm{~kg}^{-1}\right)$. Sole pea with $50 \% \mathrm{HV}+50 \% \mathrm{~T}\left(543.5 \mathrm{~g} \mathrm{~kg}^{-1}\right), 75 \% \mathrm{HV}+$ $25 \% \mathrm{~T}\left(534.5 \mathrm{~g} \mathrm{~kg}^{-1}\right), 50 \% \mathrm{CV}+50 \% \mathrm{~T}\left(503.7 \mathrm{~g} \mathrm{~kg}^{-1}\right)$, $75 \% \mathrm{CV}+25 \% \mathrm{~T}\left(501.7 \mathrm{~g} \mathrm{~kg}^{-1}\right), 50 \% \mathrm{P}+50 \% \mathrm{~T}\left(524.7 \mathrm{~g} \mathrm{~kg}^{-1}\right)$ and Sole Turnip (534.6 $\mathrm{g} \mathrm{kg}^{-1}$ ) were in the same statistical group. Legumes had the lowest ADF and NDF contens. The results are similar with the studies of Gülümser (2016), Lithourgidis et al. (2006), Aasen et al. (2004), Carr et al. (2004) and Ross et al. (2004).

$\mathrm{Ca}$ content was the highest in sole common vetch $\left(15.77 \mathrm{~g} \mathrm{~kg}^{-1}\right)$, while the lowest in $50 \% \mathrm{HV}+50 \% \mathrm{~T}(11.67$ $\mathrm{g} \mathrm{kg}^{-1}$ ) mixture. The highest $\mathrm{Mg}$ contents were in common vetch $\left(3.30 \mathrm{~g} \mathrm{~kg}^{-1}\right), 50 \% \mathrm{CV}+50 \% \mathrm{~T}\left(3.13 \mathrm{~g} \mathrm{~kg}^{-1}\right)$ and $75 \% \mathrm{CV}+25 \% \mathrm{~T}\left(3.17 \mathrm{~g} \mathrm{~kg}^{-1}\right)$. Sole pea had the lowest $\mathrm{Mg}$ content at $1.13 \mathrm{~g} \mathrm{~kg}^{-1}$. Magnesium content was increased with rising legume ratio in the combinations. Calcium and $\mathrm{Mg}$ content must be minimum $3.00 \mathrm{~g} \mathrm{~kg}^{-1}$ and $1.00 \mathrm{~g} \mathrm{~kg}^{-1}$, respectively in order to supply the animal requirement (Anonymous, 1971; Kidambi et al., 1989). The result of Ca and $\mathrm{Mg}$ contents in all treatments were above the ruminant requirements values. (Table 4 ).
The highest phosphorus content was determined in sole pea $\left(5.27 \mathrm{~kg}^{-1}\right)$. Sole pea with sole Hungarian vetch $(4.57 \mathrm{~g}$ $\mathrm{kg}^{-1}$ ) and common vetch (4.87 $\left.\mathrm{g} \mathrm{kg}^{-1}\right)$ treatments are located in the same statistical group (Table 4). In the study, $\mathrm{P}$ content of all treatments was above the value $\left(2.0 \mathrm{~g} \mathrm{~kg}^{-1}\right)$ which is necessary in forages as expressed by Maynard (1947).

Sole pea and Hungarian vetch had the highest K content at $38.97 \mathrm{~g} \mathrm{~kg}^{-1}$ and $36.70 \mathrm{~g} \mathrm{~kg}^{-1}$, respectively (Table 4). Potassium content must be $8.00 \mathrm{~g} \mathrm{~kg}^{-1}$ in the forages in order to supply the animal requirement (Anonymous, 1971; Aydin and Uzun, 2002).

Land Equivalent Ratio (LER) must be higher than 1 for showing of intercropping more advantages than sole cropping (Atis et al., 2012). According to Table 5, LER value is varying between 1.46 and $0.61(75 \% \mathrm{CV}+25 \% \mathrm{~T}$ and $75 \% \mathrm{P}+25 \% \mathrm{~T}$, respectively). $75 \% \mathrm{CV}+25 \% \mathrm{~T}$, $50 \% \mathrm{HV}+50 \% \mathrm{~T}$ and $50 \% \mathrm{CV}+50 \% \mathrm{~T}$ had more advantages compared with sole sowing due to being higher than $1(1.46,1.17$ and 1.08, respectively). Moreover, it was determine that $50 \% \mathrm{CV}+50 \% \mathrm{~T}, 50 \% \mathrm{P}+50 \% \mathrm{~T}$ and $75 \% \mathrm{P}$ $+25 \% \mathrm{~T}$ combinations which LER value was lower than 1 had lower yield compared with sole cropping.

$\mathrm{A}_{\mathrm{T}}$ values of Aggressivity were varying between -0.012 $(50 \% \mathrm{CV}+50 \% \mathrm{~T})$ and $0.006(50 \% \mathrm{P}+50 \% \mathrm{~T})$, while $\mathrm{A}_{\mathrm{L}}$ values were between $-0.006(50 \% \mathrm{P}+50 \% \mathrm{~T})$ and 0.012 $(50 \% \mathrm{CV}+50 \% \mathrm{~T})($ Table 5$) .50 \% \mathrm{HV}+50 \% \mathrm{~T}, 75 \% \mathrm{CV}+$ $25 \% \mathrm{~T}, 50 \% \mathrm{P}+50 \% \mathrm{~T}$ and $75 \% \mathrm{P}+25 \% \mathrm{~T}$ had positive value in $\mathrm{A}_{\mathrm{T}}$ and negative value in $\mathrm{A}_{\mathrm{L}}$ that demonstrates dominant specie was turnip. The negative of $\mathrm{A}_{\mathrm{T}}$ of $50 \% \mathrm{CV}$ $+50 \% \mathrm{~T}$ show that legumes were dominant species in mixture. In $75 \% \mathrm{HV}+25 \% \mathrm{~T}$, Aggressivity value at 0.00 shows that competitive ratio of Hungarian vetch and turnip were same.

In Table 5, $\mathrm{CR}_{\mathrm{T}}$ value varied between $0.30(50 \% \mathrm{CV}+$ $50 \% \mathrm{~T})$ and $2.40(50 \% \mathrm{P}+50 \% \mathrm{~T})$. High $\mathrm{CR}_{\mathrm{T}}$ value in pea intercropping showed that the competition of pea with turnip at the beginning of the flowering was lower. $\mathrm{CR}_{\mathrm{L}}$ value varied between $0.44(50 \% \mathrm{P}+50 \% \mathrm{~T})$ and 3.38 $(50 \% \mathrm{CV}+50 \% \mathrm{~T})($ Table 5$)$. In general, being low of $\mathrm{CR}_{\mathrm{L}}$ value except $50 \% \mathrm{CV}+50 \% \mathrm{~T}$ demonstrated that turnip is a dominant specie in competition with legumes in early harvest (the beginning of the flowering at the turnip). Lardner et al. (2016) were conducted a similar study in 2016.

Table 3 The average values of hay yield, protein yield, ADF and NDF of mixtures in experiment I.

\begin{tabular}{l|cccc}
\hline \multicolumn{1}{c|}{ Treatments } & Hay Yield ** $\left(\mathrm{t} \mathrm{ha}^{-1}\right)$ & Protein Yield** $\left(\mathrm{t} \mathrm{ha}^{-1}\right)$ & $\mathrm{ADF}^{* *}\left(\mathrm{~g} \mathrm{~kg}^{-1}\right)$ & $\mathrm{NDF}^{*}\left(\mathrm{~g} \mathrm{~kg}^{-1}\right)$ \\
\hline Sole Turnip & $4.54^{\mathrm{a}}$ & $0.90^{\mathrm{b}}$ & $383.00^{\mathrm{ab}}$ & $534.6^{\mathrm{abc}}$ \\
Sole H. Vetch & $2.49^{\mathrm{c}}$ & $0.56^{\mathrm{d}-\mathrm{g}}$ & $345.80^{\mathrm{bcd}}$ & $477.4^{\mathrm{bc}}$ \\
Sole C. Vetch & $1.59^{\mathrm{d}}$ & $0.41^{\mathrm{g}}$ & $303.00^{\mathrm{d}}$ & $450.2^{\mathrm{c}}$ \\
Sole Pea & $4.25^{\mathrm{a}}$ & $1.09^{\mathrm{a}}$ & $330.20^{\mathrm{bcd}}$ & $578.1^{\mathrm{a}}$ \\
$50 \% \mathrm{HV}+50 \% \mathrm{~T}$ & $4.21^{\mathrm{a}}$ & $0.78^{\mathrm{bc}}$ & $400.90^{\mathrm{a}}$ & $543.5^{\mathrm{ab}}$ \\
$75 \% \mathrm{HV}+25 \% \mathrm{~T}$ & $2.45^{\mathrm{c}}$ & $0.47^{\mathrm{fg}}$ & $402.50^{\mathrm{a}}$ & $534.5^{\mathrm{abc}}$ \\
$50 \% \mathrm{CV}+50 \% \mathrm{~T}$ & $2.40^{\mathrm{c}}$ & $0.51^{\mathrm{efg}}$ & $363.90^{\mathrm{abc}}$ & $503.7^{\mathrm{abc}}$ \\
$75 \% \mathrm{CV}+25 \% \mathrm{~T}$ & $3.49^{\mathrm{b}}$ & $0.70^{\mathrm{cd}}$ & $365.90^{\mathrm{abc}}$ & $501.7^{\mathrm{abc}}$ \\
$50 \% \mathrm{P}+50 \% \mathrm{~T}$ & $3.29^{\mathrm{b}}$ & $0.66^{\mathrm{cde}}$ & $369.90^{\mathrm{abc}}$ & $524.7^{\mathrm{abc}}$ \\
$75 \% \mathrm{P}+25 \% \mathrm{~T}$ & $2.68^{\mathrm{c}}$ & $0.62^{\mathrm{c}-\mathrm{f}}$ & $323.20^{\mathrm{cd}}$ & $484.0^{\mathrm{bc}}$ \\
\hline
\end{tabular}

**: $\mathrm{P}<0.01$. *: $\mathrm{P}<0.05, \mathrm{HV}$ : Hungarian vetch, $\mathrm{CV}$ : common vetch, $\mathrm{P}$ : pea, T: turnip. 
Table 4 The average values of $\mathrm{Ca}, \mathrm{Mg}, \mathrm{P}$ and $\mathrm{K}$ of mixtures with forage turnip, common vetch, Hungarian vetch and pea in experiment I.

\begin{tabular}{l|cccc}
\hline \multicolumn{1}{c|}{ Treatments } & $\mathrm{Ca}^{* *}\left(\mathrm{~g} \mathrm{~kg}^{-1}\right)$ & $\mathrm{Mg}^{* *}\left(\mathrm{~g} \mathrm{~kg}^{-1}\right)$ & $\mathrm{P}^{* *}\left(\mathrm{~g} \mathrm{~kg}^{-1}\right)$ & $\mathrm{K}^{* *}\left(\mathrm{~g} \mathrm{~kg}^{-1}\right)$ \\
\hline Sole Turnip & $12.33^{\mathrm{bcd}}$ & $2.07^{\mathrm{d}}$ & $4.03^{\mathrm{b}}$ & $26.33^{\mathrm{c}}$ \\
Sole H. Vetch & $13.33^{\mathrm{bcd}}$ & $2.13^{\mathrm{d}}$ & $4.57^{\mathrm{ab}}$ & $36.70^{\mathrm{ab}}$ \\
Sole C. Vetch & $15.77^{\mathrm{a}}$ & $3.30^{\mathrm{a}}$ & $4.87^{\mathrm{ab}}$ & $33.33^{\mathrm{b}}$ \\
Sole Pea & $13.70^{\mathrm{bc}}$ & $1.13^{\mathrm{e}}$ & $5.27^{\mathrm{a}}$ & $38.97^{\mathrm{a}}$ \\
$50 \% \mathrm{HV}+50 \% \mathrm{~T}$ & $11.67^{\mathrm{d}}$ & $2.20^{\mathrm{d}}$ & $4.07^{\mathrm{b}}$ & $25.37^{\mathrm{c}}$ \\
$75 \% \mathrm{HV}+25 \% \mathrm{~T}$ & $11.97^{\mathrm{cd}}$ & $2.43^{\mathrm{cd}}$ & $4.00^{\mathrm{b}}$ & $27.03^{\mathrm{c}}$ \\
$50 \% \mathrm{CV}+50 \% \mathrm{~T}$ & $14.00^{\mathrm{b}}$ & $3.13^{\mathrm{ab}}$ & $3.93^{\mathrm{b}}$ & $23.97^{\mathrm{c}}$ \\
$75 \% \mathrm{CV}+25 \% \mathrm{~T}$ & $13.70^{\mathrm{bc}}$ & $3.17^{\mathrm{ab}}$ & $4.10^{\mathrm{b}}$ & $25.73^{\mathrm{c}}$ \\
$50 \% \mathrm{P}+50 \% \mathrm{~T}$ & $12.97^{\mathrm{bcd}}$ & $2.50^{\mathrm{cd}}$ & $3.93^{\mathrm{b}}$ & $23.17^{\mathrm{c}}$ \\
$75 \% \mathrm{P}+25 \% \mathrm{~T}$ & $13.57^{\mathrm{bc}}$ & $2.73^{\mathrm{bc}}$ & $4.13^{\mathrm{b}}$ & $27.23^{\mathrm{c}}$ \\
\hline
\end{tabular}

**: P<0.01. *: P<0.05, HV: Hungarian vetch, CV: common vetch, P: pea, T: turnip.

Table 5 The average values of $\mathrm{LER}, \mathrm{A}_{\mathrm{T}}, \mathrm{A}_{\mathrm{L}}, \mathrm{CR}_{\mathrm{T}}$ and $\mathrm{CR}_{\mathrm{L}}$ of mixtures with forage turnip, common vetch, Hungarian vetch and pea in experiment I.

\begin{tabular}{l|ccccc}
\hline Treatments & LER & $\mathrm{A}_{\mathrm{T}}$ & $\mathrm{A}_{\mathrm{L}}$ & $\mathrm{CR}_{\mathrm{T}}$ & $\mathrm{CR}_{\mathrm{L}}$ \\
\hline $50 \% \mathrm{HV}+50 \% \mathrm{~T}$ & 1.17 & 0.002 & -0.002 & 1.28 & 0.83 \\
$75 \% \mathrm{HV}+25 \% \mathrm{~T}$ & 0.83 & 0.000 & 0.000 & 1.01 & 1.06 \\
$50 \% \mathrm{CV}+50 \% \mathrm{~T}$ & 1.08 & -0.012 & 0.012 & 0.30 & 3.58 \\
$75 \% \mathrm{CV}+25 \% \mathrm{~T}$ & 1.46 & 0.002 & -0.002 & 2.22 & 0.87 \\
$50 \% \mathrm{P}+50 \% \mathrm{~T}$ & 0.74 & 0.006 & -0.006 & 2.40 & 0.44 \\
$75 \% \mathrm{P}+25 \% \mathrm{~T}$ & 0.61 & 0.005 & -0.005 & & 0.48 \\
\hline
\end{tabular}

HV: Hungarian vetch, CV: common vetch, P: pea, T: turnip.

\section{Experiment II}

The effect of the intercropping on the hay yield was statistically significant $(\mathrm{P}<0.01)$ and, $50 \% \mathrm{HV}+50 \% \mathrm{~T}$ $\left(4.83 \mathrm{t} \mathrm{ha}^{-1}\right)$ treatment had the highest hay yield but it was in the same group with $50 \% \mathrm{P}+50 \% \mathrm{~T}\left(4.59 \mathrm{t} \mathrm{ha}^{-1}\right), 75 \% \mathrm{P}$ $+25 \% \mathrm{~T}\left(4.10 \mathrm{t} \mathrm{ha}^{-1}\right)$ and $75 \% \mathrm{HV}+25 \% \mathrm{~T}\left(4.32 \mathrm{tha}^{-1}\right)$. The lowest hay yield was determined in sole pea and common vetch (1.65 and $1.44 \mathrm{t} \mathrm{ha}^{-1}$, respectively).

Protein yield $(\mathrm{p}<0.01)$ was the highest in $50 \% \mathrm{P}+50 \% \mathrm{~T}$ $\left(0.93 \mathrm{t} \mathrm{ha}^{-1}\right), 75 \% \mathrm{P}+25 \% \mathrm{~T}\left(0.87 \mathrm{t} \mathrm{ha}^{-1}\right)$ and $50 \% \mathrm{HV}+$ $50 \% \mathrm{~T}\left(0.75 \mathrm{t} \mathrm{ha}^{-1}\right)$ (Table 6). Common vetch had been the lowest protein yield (0.30 tha-1) as being in the hay yield. The result suggested that protein yield in the turnip $\mathrm{X}$ legume mixtures increased with the increasing turnip ratio. This can be explained by the higher protein yield of turnip under sole sowing than legumes. Similar results were reported by Singh et al., (2010) for both harvest stages (Table 6).

ADF was detected the highest (416.90 $\mathrm{g} \mathrm{kg}^{-1}$ ) in $75 \% \mathrm{HV}+25 \% \mathrm{~T}$ treatment, however, it was in the same statistical group with $50 \% \mathrm{HV}+50 \% \mathrm{~T}, 50 \% \mathrm{P}+50 \% \mathrm{~T}$ and $75 \% \mathrm{P}+25 \% \mathrm{~T}$ treatments. For the NDF content, $75 \% \mathrm{HV}$ $+25 \% \mathrm{~T}$ had the highest value $\left(584.5 \mathrm{~g} \mathrm{~kg}^{-1}\right)$ but, except $75 \% \mathrm{CV}+25 \% \mathrm{~T}$, was in the same group with the others. In terms of $\mathrm{ADF}$ and $\mathrm{NDF}$ content, $75 \% \mathrm{CV}+25 \% \mathrm{~T}$ treatment had the lowest values $\left(321.20,459.7 \mathrm{~g} \mathrm{~kg}^{-1}\right.$, respectively). The results were similar with Lithourgidis et al. (2006), Aasen et al. (2004), Carr et al. (2004) and Ross et al. (2004).

Sole pea had the highest Ca value $\left(15.20 \mathrm{~g} \mathrm{~kg}^{-1}\right)$ and $50 \% \mathrm{P}+50 \% \mathrm{~T}\left(13.77 \mathrm{~g} \mathrm{~kg}^{-1}\right)$ were in the same statistical group. The lowest $\mathrm{Ca}$ content was in the $50 \% \mathrm{CV}+50 \% \mathrm{~T}$ (10.63 $\mathrm{g} \mathrm{kg}^{-1}$ ) (Table 7).

Sole pea had the highest $\mathrm{Mg}$ content at $3.40 \mathrm{~g} \mathrm{~kg}^{-1}$. Sole Common vetch $\left(2.90 \mathrm{~g} \mathrm{~kg}^{-1}\right), 75 \% \mathrm{CV}+25 \% \mathrm{~T}\left(2.47 \mathrm{~g} \mathrm{~kg}^{-1}\right)$ and $50 \% \mathrm{P}+50 \% \mathrm{~T}\left(2.80 \mathrm{~g} \mathrm{~kg}^{-1}\right)$ were in the same statistical group with sole pea. $75 \% \mathrm{HV}+25 \% \mathrm{~T}$ had the lowest value of $\mathrm{Mg}\left(1.77 \mathrm{~g} \mathrm{~kg}^{-1}\right.$ ) (Table 7). Ca (min 0.3\%) and $\mathrm{Mg}$ (min $0.1 \%$ ) contents of all croppings and intercroppings were higher than the necessity for animal feeding (Anonymous, 1971; Kidambi et al., 1989).

The highest $\mathrm{P}$ content was obtained in sole common vetch at $3.87 \mathrm{~g} \mathrm{~kg}^{-1}$. Moreover, $75 \% \mathrm{P}+25 \% \mathrm{~T}\left(3.83 \mathrm{~g} \mathrm{~kg}^{-1}\right)$ was in the same statistical group with sole common vetch. $\mathrm{K}$ content of treatments ranged from $29.37 \mathrm{~g} \mathrm{~kg}^{-1}(50 \% \mathrm{HV}$ $+50 \% \mathrm{~T})$ to $20.27 \mathrm{~g} \mathrm{~kg}^{-1}(50 \% \mathrm{CV}+50 \% \mathrm{~T})$ with no significant differences (Table 7). $\mathrm{P}$ and $\mathrm{K}$ content of forages were higher than the necessity values for animal feeding (Anonymous, 1971). According to the results, $\mathrm{P}$ and $\mathrm{K}$ contents of all the treatments cutted end of the turnip flowering (Exp II) was lower than those are cutted at the beginning of the flowering stage of turnip (Exp I).

Present results were similar for Hungarian vetch with the experiments of Orak et al. (2004), Copur Dogrusoz et al. (2014); for common vetch and pea with Eğritaş and Önal Aşçı, (2015), Cooper et al. (1947) and Açıkgöz et.al. (1985). This results were in harmony regarding for ADF, $\mathrm{NDF}, \mathrm{Ca}, \mathrm{Mg}, \mathrm{P}$ and $\mathrm{K}$ contents with the study of Copur Dogrusoz et al. (2014), however showed some differences for hay yield and protein yield possibilly due to the environmental factors.

LER value varied between $2.39(50 \% \mathrm{P}+50 \% \mathrm{~T})$ and $1.27(75 \% \mathrm{CV}+25 \% \mathrm{~T})$ as shown in Table 8 . This indicated that intercropping is advantageous than sole cropping when mixtures were harvested at the end of the flowering of turnip. The results are similar with findings of the Kumar et al., 2008, who reported higher LER for the intercropping system than the sole crops. 
Table 6 The average values of hay yield, protein yield, ADF and NDF of mixtures with forage turnip, common vetch, Hungarian vetch and pea in experiment II.

\begin{tabular}{l|cccc}
\hline \multicolumn{1}{c|}{ Treatments } & Hay Yield** $\left(\mathrm{t} \mathrm{ha}^{-1}\right)$ & Protein Yield** $\left(\mathrm{t} \mathrm{ha}^{-1}\right)$ & ADF $\left(\mathrm{g} \mathrm{kg}^{-1}\right)$ & $\mathrm{NDF}^{*}\left(\mathrm{~g} \mathrm{~kg}^{-1}\right)$ \\
\hline Sole Turnip & $3.66^{\mathrm{b}}$ & $0.55^{\mathrm{bc}}$ & $408.60^{\mathrm{ab}}$ & $581.6^{\mathrm{ab}}$ \\
Sole H. Vetch & $2.10^{\mathrm{cd}}$ & $0.35^{\mathrm{cd}}$ & $411.10^{\mathrm{a}}$ & $530.6^{\mathrm{ab}}$ \\
Sole C. Vetch & $1.44^{\mathrm{d}}$ & $0.30^{\mathrm{d}}$ & $355.40^{\mathrm{abc}}$ & $545.9^{\mathrm{ab}}$ \\
Sole Pea & $1.65^{\mathrm{d}}$ & $0.37^{\mathrm{cd}}$ & $360.20^{\mathrm{abc}}$ & $539.4^{\mathrm{ab}}$ \\
$50 \% \mathrm{HV}+50 \% \mathrm{~T}$ & $4.83^{\mathrm{a}}$ & $0.75^{\mathrm{ab}}$ & $414.20^{\mathrm{a}}$ & $567.1^{\mathrm{ab}}$ \\
$75 \% \mathrm{HV}+25 \% \mathrm{~T}$ & $4.32^{\mathrm{ab}}$ & $0.64^{\mathrm{b}}$ & $416.90^{\mathrm{a}}$ & $584.5^{\mathrm{a}}$ \\
$50 \% \mathrm{CV}+50 \% \mathrm{~T}$ & $3.62^{\mathrm{b}}$ & $0.61^{\mathrm{b}}$ & $323.80^{\mathrm{bc}}$ & $469.1^{\mathrm{ab}}$ \\
$75 \% \mathrm{CV}+25 \% \mathrm{~T}$ & $2.69^{\mathrm{c}}$ & $0.52^{\mathrm{bcd}}$ & $321.20^{\mathrm{c}}$ & $459.7^{\mathrm{b}}$ \\
$50 \% \mathrm{P}+50 \% \mathrm{~T}$ & $4.59^{\mathrm{a}}$ & $0.93^{\mathrm{a}}$ & $371.90^{\mathrm{abc}}$ & $525.1^{\mathrm{ab}}$ \\
$75 \% \mathrm{P}+25 \% \mathrm{~T}$ & $4.10^{\mathrm{a}}$ & $0.87^{\mathrm{a}}$ & $351.40^{\mathrm{abc}}$ & $497.9^{\mathrm{ab}}$ \\
\hline
\end{tabular}

**: $\mathrm{P}<0.01$. *: $\mathrm{P}<0.05, \mathrm{HV}$ : Hungarian vetch, $\mathrm{CV}$ : common vetch, $\mathrm{P}:$ pea, $\mathrm{T}$ : turnip.

Table 7 The average values of $\mathrm{Ca}, \mathrm{Mg}, \mathrm{P}$ and $\mathrm{K}$ of mixtures with forage turnip, common vetch, Hungarian vetch and pea in experiment II.

\begin{tabular}{l|cccc}
\hline \multicolumn{1}{c|}{ Treatments } & $\mathrm{Ca}^{* *}\left(\mathrm{~g} \mathrm{~kg}^{-1}\right)$ & $\mathrm{Mg}^{* *}\left(\mathrm{~g} \mathrm{~kg}^{-1}\right)$ & $\mathrm{P}^{*}\left(\mathrm{~g} \mathrm{~kg}^{-1}\right)$ & $\mathrm{K}\left(\mathrm{g} \mathrm{kg}^{-1}\right)$ \\
\hline Sole Turnip & $12.33^{\mathrm{bc}}$ & $2.13^{\mathrm{cde}}$ & $3.73^{\mathrm{ab}}$ & 23.00 \\
Sole H. Vetch & $12.17^{\mathrm{bc}}$ & $1.90^{\mathrm{de}}$ & $3.50^{\mathrm{ab}}$ & 29.10 \\
Sole C. Vetch & $12.23^{\mathrm{bc}}$ & $2.90^{\mathrm{ab}}$ & $2.80^{\mathrm{b}}$ & 29.07 \\
Sole Pea & $15.20^{\mathrm{a}}$ & $3.40^{\mathrm{a}}$ & $3.87^{\mathrm{a}}$ & 24.57 \\
$50 \% \mathrm{HV}+50 \% \mathrm{~T}$ & $12.40^{\mathrm{bc}}$ & $1.90^{\mathrm{de}}$ & $3.67^{\mathrm{ab}}$ & 29.37 \\
$75 \% \mathrm{HV}+25 \% \mathrm{~T}$ & $12.27^{\mathrm{bc}}$ & $1.77^{\mathrm{e}}$ & $3.5^{\mathrm{ab}}$ & 25.80 \\
$50 \% \mathrm{CV}+50 \% \mathrm{~T}$ & $10.63^{\mathrm{c}}$ & $1.93^{\mathrm{de}}$ & $3.17^{\mathrm{ab}}$ & 20.27 \\
$75 \% \mathrm{CV}+25 \% \mathrm{~T}$ & $11.50^{\mathrm{bc}}$ & $2.47^{\mathrm{b}-\mathrm{e}}$ & $3.20^{\mathrm{ab}}$ & 21.00 \\
$50 \% \mathrm{P}+50 \% \mathrm{~T}$ & $13.77^{\mathrm{ab}}$ & $2.80^{\mathrm{abc}}$ & $3.70^{\mathrm{ab}}$ & 24.10 \\
$75 \% \mathrm{P}+25 \% \mathrm{~T}$ & $13.57^{\mathrm{bc}}$ & $2.73^{\mathrm{bcd}}$ & $4.13^{\mathrm{b}}$ & 27.23 \\
\hline
\end{tabular}

**: $\mathrm{P}<0.01, *: \mathrm{P}<0.05, \mathrm{HV}$ : Hungarian vetch, $\mathrm{CV}$ : common vetch, $\mathrm{P}:$ pea, $\mathrm{T}$ : turnip.

Table 8 The average values of $\mathrm{LER}, \mathrm{A}_{\mathrm{T}}, \mathrm{A}_{\mathrm{L}}, \mathrm{CR}_{\mathrm{T}}$ and $\mathrm{CR}_{\mathrm{L}}$ of mixtures with forage turnip, common vetch, Hungarian vetch and pea in experiment 2 .

\begin{tabular}{l|ccccc}
\hline \multicolumn{1}{c|}{ Treatments } & LER & $\mathrm{A}_{\mathrm{T}}$ & $\mathrm{A}_{\mathrm{L}}$ & $\mathrm{CR}_{\mathrm{T}}$ & $\mathrm{CR}_{\mathrm{L}}$ \\
\hline $50 \% \mathrm{HV}+50 \% \mathrm{~T}$ & 1.68 & 0.003 & -0.003 & 1.19 & 0.86 \\
$75 \% \mathrm{HV}+25 \% \mathrm{~T}$ & 1.52 & 0.019 & -0.019 & 3.00 & 0.36 \\
$50 \% \mathrm{CV}+50 \% \mathrm{~T}$ & 1.67 & -0.011 & 0.011 & 0.50 & 2.03 \\
$75 \% \mathrm{CV}+25 \% \mathrm{~T}$ & 1.27 & 0.005 & -0.005 & 1.43 & 0.71 \\
$50 \% \mathrm{P}+50 \% \mathrm{~T}$ & 2.39 & -0.033 & 0.033 & 0.20 & 5.88 \\
$75 \% \mathrm{P}+25 \% \mathrm{~T}$ & 2.24 & -0.016 & 0.016 & 0.40 & 2.70 \\
\hline
\end{tabular}

HV: Hungarian vetch, CV: common vetch, P: pea, T: turnip.

Aggressivity of turnip $\left(\mathrm{A}_{\mathrm{T}}\right)$ varied between -0.033 $(50 \% \mathrm{P}+50 \% \mathrm{~T})$ and $0.019(75 \% \mathrm{HV}+25 \% \mathrm{~T})$, while aggressivity of legumes $\left(\mathrm{A}_{\mathrm{L}}\right)$ value varied between -0.019 $(75 \% \mathrm{HV}+25 \% \mathrm{~T})$ and $0.033(50 \% \mathrm{P}+50 \% \mathrm{~T})($ Table 8$) . \mathrm{It}$ is seen that turnip is a dominant species because of the positive $\mathrm{A}_{\mathrm{T}}$ in $75 \% \mathrm{HV}+25 \% \mathrm{~T}, 75 \% \mathrm{CV}+25 \% \mathrm{~T}$ and $50 \% \mathrm{HV}+50 \% \mathrm{~T}$ mixtures. Furthermore, it was determined that legume is dominant species in mixture $50 \% \mathrm{CV}+$ $50 \% \mathrm{~T}, 50 \% \mathrm{P}+50 \% \mathrm{~T}$ and $75 \% \mathrm{P}+25 \% \mathrm{~T}$.

The results of competition ratio (CR) had been confirmed with of LER and aggressivity. Competition ratio of turnip $\left(\mathrm{CR}_{\mathrm{T}}\right)$ varied between 3.00 and 0.20 and the highest value was in $75 \% \mathrm{HV}+25 \% \mathrm{~T}$ (3.00) and the second value was in $75 \% \mathrm{CV}+25 \% \mathrm{~T}$ (1.43), which is indicating that high competition potential of turnip when intercropped $\mathrm{HV}$ and $\mathrm{CV}$. Competition ratio of legume value varied between $0.36(75 \% \mathrm{HV}+25 \% \mathrm{~T})-5.88(50 \% \mathrm{P}$ $+50 \% \mathrm{~T})$. The highest $\mathrm{CR}_{\mathrm{L}}$ values were in $\% 50 \mathrm{P}+\% 50 \mathrm{~T}$ and $75 \% \mathrm{P}+\% 25 \mathrm{~T}$ and it shows that competition of pea with turnip is high compared with Hungarian vetch and common vetch.
Khan et al. (2014), who intercropped turnip and barley reported that LER was higher in mixtures compared to sole cropping with the highest in 100 barley:50 turnip treatment. also wheat-brassica intercropping produced higher economically advantage coppared its sole sowing (Akhter et al., 2004). Similarly, Srivastava \& Bohra (2006) reported that wheat and brassica intercropping was more profitable than their sole sowing.

\section{Conclusions}

This study showed that turnip $\mathrm{x}$ legume (common vetch, Hungarian vetch and pea) intercropping is more advantageous than its sole sowing with the significant effects of seed ratio and harvest stage. In general, early harvest (at the beginning of the flowering) conductions, sole turnip and sole pea exhibited higher hay and protrein yield. Also, under early harvest, sole crops produced higher protein and hay yield than its late harvest. However, under late harvest conditions (end of the flowering), turnip $\mathrm{x}$ legume intercropping were clearly more yielding compared to sole sowing. 
According to the results of this study, $50 \% \mathrm{HV}+50 \% \mathrm{~T}$ and sole pea harvested turnip at the beginig of the flowering stage of turnip were the best treatments. On the other hand, when harvest was done at end of the flowering of turnip $50 \% \mathrm{P}+50 \% \mathrm{~T}, 75 \% \mathrm{P}+25 \% \mathrm{~T}$ and $50 \% \mathrm{HV}+$ $50 \% \mathrm{~T}$ intercropping were the high yielding treatment. So for similar conditions, if harvest will be done early stage, sole sowing can be choice, but if it will be late stage, intercropping can be useful regarding hay and protein yield. Besides, it should be taken into consideration that intercropping is a supply of appropriate and healthy forage due to being easily digestible and having mineral nutrition.

\section{References}

Aasen A, Baron VS, Clayton GW, Dick AC, McCartney DH. 2004. Swath grazing potential of spring cereals, field pea and mixtures with other species. Canadian Journal of Plant Science. 84, 1051-1058. http://dx.doi.org/10.4141/P03-143.

Akhter N, Alim AMd, Islam MM, Naher Z, Rehman MA, Iqbal Hossain SM. 2004. Evaluation of mixed and intercropping of lentil and wheat. Journal Agronomy. 3: 48-51.

Anlarsal AE, Yagbasanlar T. 1996. Effect on forage production in terms of different ratios mixtures Vetch (Vicia sativa L.) with of some cereal arid conditions in Çukurova. Turkish Journal of Agriculture and Forestry. 20:157-163.

Anonymous. 1971. Nutrient requirements of beef cattle. N.A.S. Washington D.C. 55p.

Atis I, Kokten K, Hatipoglu R, Y1lmaz S, Atak M, Can E. 2012. Plant density and mixture ratio effects on the competition between common vetch and wheat. Australian Journal of Crop Science. 6(3): 498-505.

Avcioglu R, Hatipoglu R, Karadag Y. 2009. Forage Legumes, skin II. Agriculture and rural ministry directorate general of agricultural production and development. Izmir, p. 402-443.

Aydın İ, Uzun F. 2002. Meadow-pasture management and reformation. Ondokuz Mayıs University No:9, Samsun, 313 $\mathrm{p}$ (in Turkish).

Bantie YB, Abera FA, Woldegiorgis TD. 2014. Competition Indices of Intercropped Lupine (Local) and Small Cereals in Additive Series in West Gojam, North Western Ethiopia, American Journal of Plant Sciences, doi.org/10.4236/ajps.2014.59143.

Bora PC. (1999). Competition studies in intercropping of wheat (Triticum aestivum), rapeseed (Brassica campestris) and pea (Pisum sativum). Indian Journal Agronomy. 44: 509-513.

Carr PM, Horsley RD, Poland WW. 2004. Barley, oat and cerealpea mixtures as dryland forages in the Northern Great Plains. Agronomy Journal. 96: 677- 684.

Copur Dogrusoz M, Mut H, Gulumser E, Basaran U. 2014. Evaluation of Forage Yield and Quality of Forage Turnip x Legume mixtures. Mediterranean seminars. No.9 135-138p. Greece.

Eğritaş Ö, Önal Aşcı Ö. 2015. Determination of some mineral matter contents in common vetch - cereals mixtures. Academic Journal of Agriculture. 4(1):13-18.

Esmaeili A, Sadeghpourb A, Hosseini SMB, Jahanzad E, Chaichi MR, Hashemi M. 2011. Evaluation of seed yield and competition indices for intercropped barley (Hordeum vulgare) and annual medic (Medicago scutellata), International Journal of Plant Production. ISSN: 1735-6814 (Print), 1735-8043.

Gülümser E. 2016. Determination of some yield and quality characteristics of silage corn after hungarian vetch + cereals mixtures sowing in Middle Anatolia conditions. Doctorate Thesis, Ondokuz Mayıs University. The Graudate School of Natural and Applied Sciences. Samsun.
Hertrampf JW, Pascual FP. 2000. Handbook on ingredients for aquaculture feeds. Kluwer Academic Publis, Dordrecht, Boston, London. p. 573.

Khan S, Khan MA, Akmal M, Ahmad M, Zafar M, Jabeen A. 2014. Efficiency of Wheat Brassica Mixtures With Different Seed Rates in Rainfed Areas of Potohar-Pakistan. Pakistan Journal Botany. 46(2): 759-766.

Kidambi SP, Matches AG, Griggs TC. 1989. Variability for Ca, $\mathrm{Mg}, \mathrm{K}, \mathrm{Cu}, \mathrm{Zn}$ and $\mathrm{K} /(\mathrm{Ca}+\mathrm{Mg})$ ratio among 3 wheat grassess and sainfoin on the southern high plains. Journal of Range Management. 42: 316-322.

Kumar N, Prakash V, Mina BL, Gopinath KA, Srivastva AK. 2008. Evaluation of toria (Brassica campestris) and lentil (Lens culinaris) varieties in intercropping system with wheat (Triticum aestivum) under rainfed conditions. Indian $\mathrm{J}$. Agron. 53: 47-50.

Lardner HA, Kumar R, Darambazar E, Damiran D, McKinnon JJ. 2016. Comparison of Chemical Composition and Rumen Degradation Kinetics of Three Forages: Whole Plant Barley, Whole Plant Foxtail Millet and Grass-Legume Hay. Journal of Agricultural Science; Vol. 8, No. 6.

Lithourgidis AS, Vasilakoglou IB, Dhima KV, Dordas CA, Yiakoulaki MD. 2006. Forage yield and quality of common vetch mixtures with oat and triticale in two seeding ratios. Field Crops Res., 99: 106-113.

Maynard LA. 1947. Animal nutrition. 2nd edition. McGraw Hill publisher.

McGilchrist CA. 1965. Analysis of competition experiments. Biometrics, 21: 975-985.

Orak A, Ateş E, Varol F. 2004. Relationships between Some Morphological and Agricultural Properties with Nutritive Value in Hungarian Vetch (Vicia pannonica Crantz.) at Different Growth Stages. Journal of Agricultural Sciences. 10 (4) 410-415.

Rankin M. 1989. A Look at Pea and Small Grain Mixtures. (http://www.uwex.edu/ces/crops/PeaSmallGrainMix.htm).

Prakash OM. 1992. Intercropping of potato with mustard is profitable on ravine terraces of Agra. Indian Fmg. 41: 3.

Ross SM, King JR, O'Donovan JT, Spaner D. 2004. Forage Potential of Intercropping Berseem Clover with Barley, Oat, or Triticale. Agronomy Journal. 96:1013-1020.

Singh RK, Kumar H, Singh AK. 2010. Brassica Based Intercropping Systems- A Review. Institute of Agricultural Sciences, Banaras Hindu University, Varanasi - 221005 , India. Page: 253 - 266, ID: ARCC1361.

Smith RG, Atwood LW, Warren ND. 2014. Increased Productivity of a Cover Crop Mixture Is Not Associated with Enhanced Agroecosystem Services. Plos One www.plosone.org. 1-8.

Srivastava RK, Bohra TS. 2006. Performance of wheat (Triticum aestivum) + Indian mustard (Brassica juncea) intercropping in relation to row ratio, Indian mustard variety and fertility levels. Indian J. Agron., 51: 107-111.

Tan M, Serin Y. 1996. A study on the determination of optimum mixture rates and cutting stages for different vetch + cereal mixtures. Ataturk University Journal of the Faculty of Agriculture. 27 (4): 475-489.

Willey RW. 1979. Intercropping-Its importance and research needs. Part 1. Competition and yield advantages. Field Crop Abstracts. 32: 1-10.

Willey RW, Rao MR. 1980. A competitive ratio for quantifying competition between intercrops. Experimental Agriculture. 16, 117-125. doi:10.1016/j.fcr.2006.07.008 